\title{
Morphological Classification of Maize (Zea mays L.) Genotypes in Heat Stress Condition
}

\author{
Zahra Khodarahmpour \\ Department of Agronomy \& Plant Breeding, Shoushtar Branch \\ Islamic Azad University, Shoushtar, Iran \\ Tel: 98-916-618-0301_E-mail: Zahra_khodarahm@yahoo.com
}

$\begin{array}{ll}\text { Received: November 18, } 2011 & \text { Accepted: December 2, } 2011 \quad \text { Online Published: April 1, } 2012 \\ \text { doi:10.5539/jas.v4n5p31 } & \text { URL: http://dx.doi.org/10.5539/jas.v4n5p31 }\end{array}$

\begin{abstract}
This experiment was set up to understand genetic diversity in maize hybrids under heat stress condition. 30 morphological traits of 28 hybrids were studied in a randomized complete block design with three replications in 2010 at two planting dates, $6^{\text {th }}$ July (to coincide heat stress with the pollination and grain filling periods) and $27^{\text {th }}$ July (normal) in Shoushtar City in the southern part of Iran. The results showed that the traits of grain filling period, plant growth period, rows per ear and grains per ear in the both conditions had positive and significant correlation with grain yield. Under heat stress condition however, the highest coefficient of phenotypic variation was obtained for grain yield, grains per ear, grains per row and ASI, and in normal condition for grain abortion percentage and ASI. Cluster analysis by Ward's minimum variance, clustered hybrids in to three groups for both conditions. Hybrids $\mathrm{K} 18 \times \mathrm{K} 166 \mathrm{~B}$ and $\mathrm{K} 18 \times \mathrm{K} 47 / 2-2-1-21-2-1-1-1$ in the second cluster from the heat stress condition and hybrids $\mathrm{K} 18 \times \mathrm{K} 166 \mathrm{~B}, \mathrm{~K} 166 \mathrm{~A} \times \mathrm{K} 3640 / 5, \mathrm{~K} 166 \mathrm{~A} \times \mathrm{K} 47 / 2-2-1-21-2-1-1-1$ and $\mathrm{K} 166 \mathrm{~A} \times \mathrm{K} 19$ in second cluster from the normal condition were found to be the most suitable because they had higher values for grain yield and other desirable traits and lower grain abortion percentage, ASI and grain protein percentage. Therefore, in accordance with the cluster analysis these aforementioned hybrids would be the most suitable for cultivation under the studied conditions.
\end{abstract}

Keywords: Cluster analysis, Heat stress, Maize, Morphological traits

\section{Introduction}

Maize (Zea mays L.), is a cereal with a remarkable potential for production, it is the third most important grain crop after wheat and rice and it accounts for $4.8 \%$ of the total cropped land area and $3.5 \%$ of the value of agricultural output (Ahmad et al., 2011).

Temperature is one of the most important environmental parameters affecting maize crops. The heat tolerance of plants is a complex trait, most probably controlled by multiple genes (Zhang et al., 2005), so the primary aim of cereal breeding must be to develop stress tolerant cultivars (Tester and Bacic, 2005). Temperature stress can reduce maize quality and yield; and any further rise in temperature reduces its pollen viability and silk receptivity, resulting in poor seed set and reduced grain yield (Johnson, 2000; Aldrich et al., 1986; Samuel et al., 1986).

In the southern part of Iran, especially in Khuzestan, high temperature stress is one of the most important abiotic stresses affecting the maize growing area. The climate of Khuzestan is generally hot and occasionally humid. Summertime temperatures routinely exceed 50 degrees Celsius (record striking temperatures of over 60 degrees air temperature also occur with up to 90 degrees surface temperature) Khuzestan province is known to master the hottest temperatures on record for a populated city anywhere in the world. The abundance of water and fertility of soil have transformed this region into a rich and well-endowed land. Increasing heat tolerance of hybrids is the main focus for maize breeders, and to achieve this, it is necessary to test combinations under both normal and heat stress conditions.

Information obtained from correlation coefficients for these characters could be useful indicators of the more important considerations (Sadek et al., 2006). Saed Moshchi et al. (2010) reported that under drought stress rows 
per ear had the most positive correlation and grains per row had the least correlation with grain yield. Ihsan et al. (2005) also reported significant genetic differences for morphological traits for maize genotypes.

The strategies used in maize breeding programs (Zea mays L.) are frequently characterized by a decrease of genetic diversity in the pool of germplasms hence an increase in genetic evenness in cereal production (Lee, 1998). This might cause important problems, in particular an increased sensitivity to new diseases and/or decreased tolerance to high temperature or drought (Du-vick, 1989). The assessment of genetic diversity within and among populations has been the concern of several researchers in the past decade. Such assessments are especially important to plant genetic resource management programs (Bretting and Widrlechner, 1995).

Cluster analysis is a convenient method for organizing data sets so that information can be retrieved more efficiently and be easily understood without the need for complicated mathematical techniques. Data can nominally be summarized by a small number of groups of objects in a dendrogram generated by cluster analysis. Many tools are now available to study relationships among cultivars, including various types of molecular markers; however, morphological characterization is the first step in the description and classification of germplasm (Smith and Smith, 1989). Ruiz de Galarreta and Alvarez (2001) in a study of one hundred landraces of maize from Northern Spain on the basis of twenty-two morphological traits, and seventeen ecological variables associated with the collection site, the study reported that seven different groups were obtained from the cluster analysis using plant and cycle traits. Seven populations with promising breeding values were detected. Golbashy et al. (2010) used cluster analysis as a method of classification based on stress tolerance and susceptibility indices on grain yield in both normal and stress conditions. The hybrids were classified in to three groups with low, intra- and high extra-group similarities. Khodarahmpour and Choukan (2011) studied fifteen inbred lines and reported that under heat stress condition the highest coefficient of phenotypic variation was obtained for ASI, grains per ear, grains per row and grain yield and in normal condition for grain abortion percentage and ASI. The lines were clustered in to three groups in both conditions. Lines K166A and K166B in the third cluster from heat stress condition; and lines K19, K3651/2, K166B and K47/2-2-1-3-3-1-1-1 in the third cluster from normal condition were found to be the most suitable because they had higher values for yield and other desirable traits, therefore, good potential for use in hybridization programs.

The objectives of this study were: (1) to characterize and choose the plant traits that best explain genetic variation; and (2) to group twenty eight maize hybrids according to thirty morphological traits under normal and heat stress conditions.

\section{Materials and Methods}

\subsection{Study Site and Experiment Details}

The study was conducted at Shoushtar City located in Khuzestan province, Iran (32 $2^{\prime} \mathrm{N}$ and $48^{\circ} 50^{\prime} \mathrm{E}, 150 \mathrm{~m}$ asl) during 2010. The experiment evaluated 28 hybrids (Table 2) from a combination of eight selected inbred lines (Table 1). The hybrids were planted in two separate experiments on two planting dates; $6^{\text {th }}$ July (to coincide with heat stress at during pollination and grain filling periods), and $27^{\text {th }}$ July for normal planting. The soil type at this location was clay loam, $\mathrm{pH}=7.6$ with $\mathrm{EC}=0.5 \mathrm{mmhos} / \mathrm{cm}$. The experiment used a randomized complete block design with three replications and was performed in Shoushtar City in southern Iran. The plot (hybrid) was made of three rows of $9 \mathrm{~m}$ length with the distance between rows and hills of 75 and $20 \mathrm{~cm}$, respectively. Sowing was performed by two seeds per hill and thinning 18 days after planting reduced the stand at one plant per hill. The seedlings were irrigated every five days, fertilizers were applied prior to sowing at a rate of $120 \mathrm{~kg} \mathrm{~N} \mathrm{ha}^{-1}$ and $140 \mathrm{~kg} \mathrm{P} \mathrm{ha}{ }^{-1}$, and an additional side dressing of $120 \mathrm{~kg} \mathrm{~N} \mathrm{ha}^{-1}$ was applied at the six-leaf stage. Minimum and maximum air temperatures at the time of pollination were $30^{\circ} \mathrm{C}$ and $46^{\circ} \mathrm{C}$ under heat stress condition (planting date $6^{\text {th }}$ July) and $25^{\circ} \mathrm{C}$ and $38^{\circ} \mathrm{C}$ under normal condition (planting date $27^{\text {th }}$ July) (Table 3 ).

\subsection{Data Collection and Analysis}

Data on plant traits were recorded for five plants per hybrid in per plot (randomly selected). Traits included ASI (Anthesis Silking Interval), grain filling period, plant growth period, grains per row, rows per ear, grains per ear, ear diameter, cob diameter, grain depth, grain diameter, grain width, grain abortion percentage, ear height, plant height, ear-up leaves (The leaves located above the internode at which the main ear as drown), ear-down leaves (The leaves located down the internode at which the main ear as drown), total leaves, branch number, tassel length, tassel up, peduncle-In, peduncle-out, peduncle length (a stalk supporting an inflorescence, which is the part of the shoot of seed plants where flowers are formed), 1000-grain weight and hektolitr weight. Data for grain yield, grain dry matter weight, grain moisture percentage and grain protein percentage (Galicia et al., 2008) were also collected. 
Analysis of variance, phenotypic correlation, descriptive statistics and cluster analysis (Ward's minimum variance method) used the SPSS var. 16 software. All of the investigated traits were subjected to hierarchical cluster analysis.

\section{Results and Discussion}

Significant differences were observed among the hybrids in both conditions for all the studied traits (Data not shown) except grain width, grain dry matter weight and grain filling rate in normal condition that indicated the variation among hybrids for the studied traits. Ihsan et al. (2005) also reported significant genetic differences for morphological traits between maize genotypes.

\subsection{Phenoyypic Correlation}

Results of correlation coefficients in heat stress condition (Table 4) showed that grain yield with grain filling period, plant growth period, ear height, plant height, ear-down leaves, total leaves, peduncle-out, rows per ear, grains per row, grains per ear, ear diameter, grain depth, grain dry matter weight and 1000-grain weight all had significant and positive correlation, with grain filling rate, grain abortion percentage and grain protein percentage had significant and negative correlation and for the other traits there was no correlation.

But, in normal condition (Table 4) grain yield with grain filling period, plant growth period, rows per ear and grains per ear all had significant and positive correlation, with ASI significant and negative correlation and with other traits there was no correlation. Khodarahmpour and Choukan (2011) in a study of fifteen inbred lines under heat stress and normal conditions reported that grain yield with rows per ear, grains per row, grains per ear, grain depth, grain dry matter weight, 1000-grain weight, ear-down leaves, total leaves, branch number, ear diameter and grain diameter had significant and positive correlation; that grain protein percentage had significant and negative correlation, and with other traits there was no correlation. But, in normal condition grain yield with grain filling period, grains per ear, total leaves, grain width, grains per row, grain depth and ear-down leaves had significant and positive correlation, with ASI and grain protein percentage had significant and negative correlation; and with other traits there was no correlation. Fowler (2003) and Lemon (2007) reported that grain protein percentage is negatively correlated with grain yield in stress condition. Saed Moshchi et al. (2010) reported that under the drought stress condition rows per ear had the most positive correlation and grains per row had the least correlation with grain yield.

\subsection{Coefficient of Phenotypic Variation}

Arithmetic means, standard deviation and coefficient of phenotypic variation of traits are shown in Table 4. Under heat stress condition, the highest coefficient of phenotypic variation was obtained for grain yield (79\%), grains per ear $(74 \%)$, grains per row $(68 \%)$. But, the lowest coefficient of phenotypic variation was obtained for hektolitr weight (5\%), total leaves $(5.5 \%)$ and plant growth period (6\%).

Under the normal condition the highest coefficient of phenotypic variation was obtained for grain abortion percentage $(71 \%)$ and ASI $(50 \%)$. But, the lowest coefficient of phenotypic variation was obtained for plant growth period (4\%), hektolitr weight (6\%), ear-up leaves $(6 \%)$, total leaves $(6 \%)$ and rows per ear $(6 \%)$ (Table 3). Khodarahmpour and Choukan (2011) in a study on fifteen inbred lines showed that under heat stress condition, the highest coefficient of phenotypic variation was obtained for ASI, grains per ear, grains per row and grain yield and in normal condition for grain abortion percentage and ASI. Abayi et al. (2004) reported significant genetic variation in important agronomic traits. The results of Jotshi et al. (1988), Alvarez and Lasa (1994), Lu et al. (1994) and Zhang et al. (1995) demonstrated the importance of quantifying genetic variability among maize cultivars grown in an area before initiation of a breeding program.

\subsection{Classification of Hybrids via Cluster Analysis}

Cluster analysis was done using the data for thirty morphological traits under both conditions. Results of the cluster analysis (Ward's minimum variance method) showed clustered hybrids with cut dendrogram in interval 5 to three groups in the both conditions (Figures 1 and 2). In the heat stress condition, the first cluster included 20 of the hybrids and for the traits of grain protein percentage, grain moisture percentage, grain abortion percentage, plant height, ear height, branch number and peduncle-in results were higher than the total mean and were lower than the total mean for the other traits and/or had no difference from the total mean (Table 5). The second cluster included two hybrids for all desirable traits; grain yield, grain filling period, grain filling rate, plant growth period, grain dry matter weight, 1000-grain weight, hektolitr weight, grains per row, rows per ear, grains per ear, ear diameter, grain depth, grain diameter, plant height, ear height, ear-up leaves, ear-down leaves, tassel length, tassel up, peduncle-out and peduncle length results were higher than the total mean and were lower than the total mean for the other traits and/or had no difference from the total mean (Table 5). The third cluster included six 
hybrids for all traits except ASI, grain filling rate, grain protein percentage, grain abortion percentage, ear-up leaves, ear-down leaves, total leaves, tassel length, tassel up and peduncle length results were higher than the total mean (Table 5).

In the normal condition, the first cluster included twenty one hybrids for traits of grain yield, ASI, hektolitr weight, grains per row, grains per ear, peduncle-in and peduncle length, results were higher than total mean and lower than the total mean for other traits and/or had no difference from the total mean (Table 6). The second cluster included four hybrids for all traits; ASI, grain protein percentage, hektolitr weight, grains per row, grain width, grain abortion percentage, ear height, ear-up leaves, total leaves and peduncle-in it results were lower than the total mean and for other traits it was the higher than the total mean and/or had no difference from the total mean (Table 6). The third cluster included three hybrids for traits of grain filling rate, grain dry matter weight, grain moisture percentage, grains per ear, grain abortion percentage, plant height, ear height, tassel length and tassel up, it results were higher than that of total mean and lower than the total mean for other traits and/or had no difference from the total mean (Table 6).

With attention to the research findings of Jones et al. (1985) and Johnson (2000) which demonstrated that an increase of temperature caused an increase in grain abortion percentage; and the report of Lauer (2006), also showing that heat stress prevented the synchronization between pollen fall and silk appearance and resulted in increased grain abortion, it is hybrids of the second cluster are recommended for cultivation because they had higher values for yield ASI and grain protein percentage and other desirable traits and lower grain abortion percentages. Also, the hybrids of the second cluster had good results under the normal condition.

Ruiz de Galarreta and Alvarez (2001) in a study of one hundred landraces of maize from Northern Spain on the basis of twenty-two morphological traits, and seventeen ecological variables associated with the collection site, the study reported that seven different groups were obtained from the cluster analysis using plant and cycle traits. Seven populations with promising breeding values were detected. Golbashy et al. (2010) used cluster analysis as a method of classification based on stress tolerance and susceptibility indices on grain yield in both normal and stress conditions. The hybrids were classified in to three groups with low, intra- and high extra-group similarities. Khodarahmpour and Choukan (2011) studied fifteen inbred lines and reported that under heat stress condition the highest coefficient of phenotypic variation was obtained for ASI, grains per ear, grains per row and grain yield and in normal condition for grain abortion percentage and ASI. The lines were clustered in to three groups in both conditions. Lines K166A and K166B in the third cluster from heat stress condition; and lines K19, K3651/2, K166B and K47/2-2-1-3-3-1-1-1 in the third cluster from normal condition were found to be the most suitable because they had higher values for yield and other desirable traits, therefore, good potential for use in hybridization programs.

\section{Conclusion}

Results from hybrids grown under heat stress condition showed that grain yield with grain filling period, plant growth period, ear height, plant height, ear-down leaves, total leaves, peduncle-out, rows per ear, grains per row, grains per ear, ear diameter, grain depth, grain dry matter weight and 1000-grain weight all had significant and positive correlation with grain filling rate, grain abortion percentage and grain protein percentage had significant and negative correlation and that with the other traits there was no correlation. But, in normal condition grain yield with grain filling period, plant growth period, rows per ear and grains per ear all had significant and positive correlation, with ASI and significant and negative correlation, but with the other traits there was no correlation. Therefore the traits of grain filling period, plant growth period, rows per ear and grains per ear in both conditions had positive and significant correlation with grain yield.

Under the heat stress condition, the highest coefficient of phenotypic variation was obtained for grain yield, grains per ear, grains per row and ASI. But, the lowest coefficient of phenotypic variation was obtained for hektolitr weight, total leaves and plant growth period. Therefore in this case, it can be said that these traits, in terms of being genetic resources in this study, had low range for use in selection projects. Also, under heat stress condition there was high diversity in the traits of grains per ear and grains per row and with attention to the high correlation that these traits had with grain yield, these traits can be used as important factors in indexes for the selection of hybrids in heat stress condition. Under normal condition the highest coefficient of phenotypic variation was obtained for grain abortion percentage and ASI. But, the lowest coefficient of phenotypic variation was obtained for hektolitr weight, ear-up leaves, total leaves, rows per ear and plant growth period. With attention to high correlation and negative ASI with grain yield, the minimum of ASI was the most important index in the selection of hybrids with high grain yield in normal condition. 
Cluster analysis by Ward's minimum variance, clustered hybrids in to three groups in both conditions. Hybrids $\mathrm{K} 18 \times \mathrm{K} 166 \mathrm{~B}$ and $\mathrm{K} 18 \times \mathrm{K} 47 / 2-2-1-21-2-1-1-1$ in the second cluster in the heat stress condition and hybrids $\mathrm{K} 18 \times \mathrm{K} 166 \mathrm{~B}, \mathrm{~K} 166 \mathrm{~A} \times \mathrm{K} 3640 / 5, \mathrm{~K} 166 \mathrm{~A} \times \mathrm{K} 47 / 2-2-1-21-2-1-1-1$ and $\mathrm{K} 166 \mathrm{~A} \times \mathrm{K} 19$ in the second cluster in the normal condition were the most suitable because they had higher values for grain yield and other desirable traits and lower grain abortion percentages, ASI and grain protein percentage indications that show that hybrids of these clusters are suitable for cultivation under the studied conditions. In both conditions the joint hybrids $\mathrm{K} 18 \times \mathrm{K} 166 \mathrm{~B}$ and $\mathrm{K} 18 \times \mathrm{K} 47 / 2-2-1-21-2-1-1-1$, are recommended for cultivation in heat stress and normal conditions.

\section{Acknowledgements}

The corresponding author gratefully acknowledges the funding from the Islamic Azad University, Shoushtar branch through Grant.

\section{References}

Abayi, I. K., Ojo, A. A., Kalu, B. A., \& Adeyemo, M. O. (2004). Genetic variability, heritability and genetic variance in $\mathrm{S}_{1}$ progenies of extra-early and early maize (Zea mays L.) population. Journal Sustainable Agriculture Environment, 6, 179-184.

Ahmad, S. Q., Khan, S., Ghaffar, M., \& Ahmad, F. (2011). Genetic Diversity Analysis for Yield and Other Parameters in Maize (Zea mays L.) Genotypes. Asian Journal of Agricultural Science, 3(5), 385-388.

Aldrich, S. R., Scott, W. O., \& Hoeft, R. G. (1986). Modern Maize Production. 3th Edition, A and L publications, Inc., Station A, Box F, Champaign, Illinois 61820.

Alvarez, A., \& Lasa, J. M. (1994). Collecting and preliminary evaluation of local maize in northern Spain. Plant Genetic Resources Newsletter, 100, 21-23.

Bretting, P. K., \& Goodman, M. M. (1989). Karyological variation in Mesoamerican races of maize and its systematic significance. Economical Botany, 43, 107-124. http://dx.doi.org/10.1007/BF02859330

Duvick, D. (1989). Possible genetic causes of increased variability in U.S. maize yields. Pages 147-156. In: J. R. Yerson and P.B.R. Hazell (eds.). Variability in Grain Yields: Implications for Agricultural Research and Policy in Developing Countries. Johns Hopkins University Press, Baltimore, MD.

Fowler, D. B. (2003). Crop nitrogen demand and grain protein concentration of spring and winter wheat. Agronmy Journal, 95, 260- 265. http://dx.doi.org/10.2134/agronj2003.0260

Galicia, L., Nurit, E., Rosales, A., \& Palacios - Rojas, N. (2008). Maize nutrition quality and plant tissue analysis laboratory, CIMMYT, 42p.

Golbashy, M., Khavari Khorasani, S., Ebrahimi, M., \& Choucan, R. (2010). Evaluation of drought tolerance of some corn (Zea mays L.) hybrids in Iran. African Journal of Agricultural Research, 5(19), 2714-2719

Ihsan, H., Khalil, I. H., Rehman, H., \& Iqbal, M. (2005). Genotypic Variability for morphological traits among exotic maize hybrids. Sarhad Journal of Agriculture, 21(4), 599-602.

Johnson, C. (2000). Ag answers: post-pollination period critical to maize yields. Agricultural Communication Service, Purdue University. 42p.

Jones, R. J., Roessler, J. A., \& Ouattar, S. (1985). Thermal environment during endosperm cell division in maize: Effects on number of endosperm cells and starch granules. Crop Science, 25, 830-834. http://dx.doi.org/10.2135/cropsci1985.0011183X002500050025x

Jotshi, P. N., Bhat, B. K., \& Bhan, M. K. (1988). Genetic variability and character association in maize grown in Jammu province. Maize Genetic Cooperation Newsletter, 62, 105-106.

Khodarahmpour, Z., \& Choukan, R. (2011). Study of the Genetic Variation of Maize (Zea mays L.) Inbred Lines in Heat Stress Condition Using Cluster Analysis. Seed and Plant Journal, 1-27(4).

Lauer, J. (2006). Concerns about drought as maize pollination begins. Wiscousin Crop Manager.

Lee, M. (1998). Genome projects and gene pools: New germplasm for plant breeding? Proceedings of the National Academy of Sciences, 95, 2001-2004. http://dx.doi.org/10.1073/pnas.95.5.2001

Lemon, J. (2007). Nitrogen management for wheat protein and yield in the sperance port zone. Department of Agriculture and Food Publisher, 25p. 
Lu, H., Zheng, Y. L., Xiong, X. Z., Li, J. S., Xiong, Z., \& Liu, J. L. (1994). Allozyme polymorphism within and among local varieties of maize in southwestern China. Maize Genetic Cooperation Newsletter, 68, 113-115.

Ruiz de Galarreta, J. I., \& Alvarez, A. (2001). Morphological classification of maize landraces from Northern Spain. Genctic Resources of Crop Evolution, 48, 391-400. http://dx.doi.org/10.1023/A:1012074606561

Sadek, S. E., Ahmed, M. A., \& Abd-El-Ghaney, H. M. (2006). Correlation and path coefficient analysis in parents inbred lines and their six white corn (Zea mays L.) single crosses developed and grown in Egypt. Journal of Applied Science Research, 2(3), 159-167.

Saed Moshchi, A., Piraste Anoshe, H., \& Zare, S. (2010). The $11^{\text {th }}$ Crop Production \& Breeding Congress Iran, University of Shahid Beheshti. P 472-475.

Samuel, R. A., Scott, W. O., \& Hoft, R. G. (1986). Modern Maize Production. 3th Edition. A and L publishers, Inc., Station A, Box F, Champaign, Illinois 61820. Similar to reference No. 2.

Smith, J. S. C., \& Smith, O. S. (1989). The description and assessment of distances between inbred lines of maize: The utility of morphological, biochemical, and genetic descriptors and a scheme for the testing of distinctiveness between inbred lines. Maydica, 34,151-161.

Tester, M., \& Bacic, M. (2005). Abiotic stress tolerance in grasses. From model plants to crop plants. Plant Physiology, 137, 791-793. http://dx.doi.org/10.1104/pp.104.900138

Zhang, Y., Mar, M., Chekhovsky, K., Kupfer, D., Lai, H., \& Roe, B. A. (2005). Differential gene expression in Festuca under heat stress conditions. Journal of Experimental Botany, 56, 897-907. http://dx.doi.org/10.1093/jxb/eri082

Zhang, Z. X., Zheng, Y. L., Li, J. S., \& Liu, J. L. (1995). Allozyme polymorphism and relationships to quantitative traits: diversity of 10 local varieties. Maize Genetic Cooperation Newsletter, 69, 138-142.

Table 1. Some characteristics studied inbred lines

\begin{tabular}{|l|l|}
\hline Inbred lines & Pedigree sources/origin \\
\hline Lancaster Sure Crop (LSC) & \\
MO17 & CI. 187-2 $\times$ C103 \\
K18 & Derived from MO17 changes in Iran \\
K19 & Derived from MO17 changes in Iran \\
K19/1 & Derived from K19 changes in Iran \\
\hline Reid Yellow Dent (RYD) & \\
B73 & BSSS C5(Iowa Stiff Stalk Synthetic) \\
A679 & A B73 back-cross derived line \\
\hline Extracted from late synthetic (Created in Iran) & [(A662 $\times$ B73)(3)] \\
K3651/1 & SYN-Late(Iran) \\
K3640/5 & SYN-Late(Iran) \\
K3651/2 & SYN-Late(Iran) \\
\hline Lines extracted from CIMMYT originated materials in Iran & \\
K166A & \\
K3544/1 & \\
K166B & \\
\hline Lines extracted from Unknown materials in Iran & \\
K74/1 & \\
K47/2-2-21-2-1-1-1 & \\
K47/2-2-1-3-3-1-1-1 & \\
\hline
\end{tabular}


Table 2. Types of hybrids produced by crosses of inbred lines

\begin{tabular}{|c|c|c|c|}
\hline Number & Hybrid & Number & Hybrid \\
\hline 1 & $\mathrm{~K} 18 \times \mathrm{K} 3651 / 1$ & 15 & $\mathrm{~A} 679 \times \mathrm{K} 166 \mathrm{~B}$ \\
\hline 2 & $\mathrm{~K} 18 \times \mathrm{A} 679$ & 16 & A679×K3640/5 \\
\hline 3 & $\mathrm{~K} 18 \times \mathrm{K} 166 \mathrm{~A}$ & 17 & A679×K47/2-2-1-21-2-1-1-1 \\
\hline 4 & $\mathrm{~K} 18 \times \mathrm{K} 166 \mathrm{~B}$ & 18 & A679×K19 \\
\hline 5 & $\mathrm{~K} 18 \times \mathrm{K} 3640 / 5$ & 19 & $\mathrm{~K} 166 \mathrm{~A} \times \mathrm{K} 166 \mathrm{~B}$ \\
\hline 6 & $\mathrm{~K} 18 \times \mathrm{K} 47 / 2-2-1-21-2-1-1-1$ & 20 & $\mathrm{~K} 166 \mathrm{~A} \times \mathrm{K} 3640 / 5$ \\
\hline 7 & $\mathrm{~K} 18 \times \mathrm{K} 19$ & 21 & $\mathrm{~K} 166 \mathrm{~A} \times \mathrm{K} 47 / 2-2-1-21-2-1-1-1$ \\
\hline 8 & $\mathrm{~K} 3651 / 1 \times \mathrm{A} 679$ & 22 & $\mathrm{~K} 166 \mathrm{~A} \times \mathrm{K} 19$ \\
\hline 9 & $\mathrm{~K} 3651 / 1 \times \mathrm{K} 166 \mathrm{~A}$ & 23 & $\mathrm{~K} 166 \mathrm{~B} \times \mathrm{K} 3640 / 5$ \\
\hline 10 & K3651/1×K166B & 24 & $\mathrm{~K} 166 \mathrm{~B} \times \mathrm{K} 47 / 2-2-1-21-2-1-1-1$ \\
\hline 11 & $\mathrm{~K} 3651 / 1 \times \mathrm{K} 3640 / 5$ & 25 & $\mathrm{~K} 166 \mathrm{~B} \times \mathrm{K} 19$ \\
\hline 12 & $\mathrm{~K} 3651 / 1 \times \mathrm{K} 47 / 2-2-1-21-2-1-1-1$ & 26 & $\mathrm{~K} 3640 / 5 \times \mathrm{K} 47 / 2-2-1-21-2-1-1-1$ \\
\hline 13 & $\mathrm{~K} 3651 / 1 \times \mathrm{K} 19$ & 27 & $\mathrm{~K} 3640 / 5 \times \mathrm{K} 19$ \\
\hline 14 & $\mathrm{~A} 679 \times \mathrm{K} 166 \mathrm{~A}$ & 28 & $\mathrm{~K} 47 / 2-2-1-21-2-1-1-1 \times \mathrm{K} 19$ \\
\hline
\end{tabular}

Table 3. Average minimum and maximum temperature of research farm in heat stress and normal conditions in 2010

\begin{tabular}{|l|l|l|}
\hline \multirow{2}{*}{ Months } & \multicolumn{2}{|l|}{ Temperature $\left({ }^{\circ} \mathrm{C}\right)$} \\
\cline { 2 - 3 } & Minimum & Maximum \\
\hline July & $31^{\circ} \mathrm{C}$ & $46^{\circ} \mathrm{C}$ \\
\hline August & $32^{\circ} \mathrm{C}$ & $46^{\circ} \mathrm{C}$ \\
\hline September & $30^{\circ} \mathrm{C}$ & $46^{\circ} \mathrm{C}$ \\
\hline October & $25^{\circ} \mathrm{C}$ & $38^{\circ} \mathrm{C}$ \\
\hline November & $17^{\circ} \mathrm{C}$ & $27^{\circ} \mathrm{C}$ \\
\hline
\end{tabular}

Table 4. Descriptive statistics and coefficient of phenotypic variation and correlation of the traits with grain yield in maize hybrids under heat stress and normal conditions

\begin{tabular}{|c|c|c|c|c|c|c|c|c|}
\hline \multirow[t]{2}{*}{ Traits } & \multicolumn{2}{|c|}{ Mean } & \multicolumn{2}{|c|}{$\begin{array}{c}\text { Standard } \\
\text { deviation }\end{array}$} & \multicolumn{2}{|c|}{ Phenotypic cv(\%) } & \multicolumn{2}{|c|}{ Correlation } \\
\hline & Normal & Stress & Normal & Stress & Normal & Stress & Normal & Stress \\
\hline Grain yield $\left(\mathrm{Kgha}^{-1}\right)$ & 3135 & 953 & 837.9 & 754.5 & 27 & 79 & - & - \\
\hline ASI (day) & 2.2 & 3 & 1.1 & 1.3 & 50 & 43 & $-0.42 *$ & $0.14 \mathrm{~ns}$ \\
\hline Grain filling period (day) & 71 & 65 & 5.4 & 7.3 & 8 & 11 & $0.43 *$ & $0.49 * *$ \\
\hline Grain filling rate $\left(\right.$ mgday $\left.^{-1}\right)$ & 4.1 & 4.1 & 0.55 & 0.56 & 13 & 14 & $0.097 \mathrm{~ns}$ & $-0.65^{* *}$ \\
\hline Plant growth period (day) & 126.3 & 124 & 5 & 7.1 & 4 & 6 & $0.73 * *$ & $0.54 *$ \\
\hline Grain protein percentage & 7.9 & 12.7 & 1.1 & 1.4 & 14 & 11 & $-0.14 n s$ & $-0.65 * *$ \\
\hline Grain dry matter weight (mg) & 293.8 & 267.6 & 38.8 & 34.6 & 13 & 13 & $0.32 \mathrm{~ns}$ & $0.87 *$ \\
\hline 1000 grain weight (gr) & 334 & 324.4 & 59.8 & 58.8 & 18 & 18 & $0.33 \mathrm{~ns}$ & $0.56^{* *}$ \\
\hline Hektolitr weight $\left(\mathrm{grl}^{-1}\right)$ & 701.4 & 730.4 & 41.4 & 33.5 & 6 & 5 & $-0.08 \mathrm{~ns}$ & $0.25 \mathrm{~ns}$ \\
\hline Grain moisture percentage & 24.7 & 15.3 & 1.8 & 2 & 7 & 13 & $0.07 \mathrm{~ns}$ & $-0.13 n s$ \\
\hline Grain per row & 30 & 7.3 & 6.6 & 5 & 22 & 68 & $0.07 \mathrm{~ns}$ & $0.74 * *$ \\
\hline Rows per ear & 14 & 10 & 0.79 & 2.5 & 6 & 25 & $0.53 * *$ & $0.68 * *$ \\
\hline Grain per ear & 431 & 90 & 95 & 66.5 & 22 & 74 & $0.40^{*}$ & $0.80 * *$ \\
\hline Ear diameter $(\mathrm{cm})$ & 4.1 & 3.1 & 0.34 & 0.3 & 8 & 10 & $0.19 \mathrm{~ns}$ & $0.67 * *$ \\
\hline Ear wood diameter $(\mathrm{cm})$ & 2.4 & 2.2 & 0.2 & 0.21 & 8 & 10 & $0.24 \mathrm{~ns}$ & $0.18 \mathrm{~ns}$ \\
\hline Grain depth $(\mathrm{cm})$ & 0.9 & 0.45 & 0.15 & 0.12 & 17 & 27 & $0.097 \mathrm{~ns}$ & $0.81 * *$ \\
\hline Grain width $(\mathrm{cm})$ & 0.44 & 0.59 & 0.07 & 0.07 & 16 & 11 & $0.18 \mathrm{~ns}$ & $0.13 \mathrm{~ns}$ \\
\hline Grain diameter $(\mathrm{cm})$ & 0.68 & 0.69 & 0.06 & 0.07 & 9 & 10 & $0.1 \mathrm{~ns}$ & $0.42 * *$ \\
\hline Grain abortion percentage & 3.5 & 34.6 & 2.5 & 15.6 & 71 & 45 & $-0.15 \mathrm{~ns}$ & $-0.42 *$ \\
\hline Plant height $(\mathrm{cm})$ & 150.8 & 130.9 & 12 & 26.9 & 8 & 21 & $-0.17 \mathrm{~ns}$ & $0.53 * *$ \\
\hline Ear height $(\mathrm{cm})$ & 66.9 & 56 & 7.6 & 15 & 11 & 27 & $-0.096 \mathrm{~ns}$ & $0.46^{*}$ \\
\hline Ear-up leaves & 5.6 & 6 & 0.33 & 0.49 & 6 & 8 & $0.24 \mathrm{~ns}$ & $0.26 \mathrm{~ns}$ \\
\hline Ear-down leaves & 6 & 6 & 0.52 & 0.69 & 9 & 11.5 & $0.05 \mathrm{~ns}$ & $0.40^{*}$ \\
\hline Total leaves & 12 & 12 & 0.7 & 0.66 & 6 & 5.5 & $0.09 \mathrm{~ns}$ & $0.58 * *$ \\
\hline Tassel length (cm) & 36 & 36.2 & 4 & 2.7 & 11 & 7.5 & $-0.17 \mathrm{~ns}$ & $0.05 \mathrm{~ns}$ \\
\hline Tassel up (cm) & 26 & 26 & 3.2 & 2.1 & 12 & 8 & $-0.16 \mathrm{~ns}$ & $0.12 \mathrm{~ns}$ \\
\hline Branch number & 12.7 & 13.6 & 2.1 & 2 & 16.5 & 15 & $0.14 \mathrm{~ns}$ & $0.07 \mathrm{~ns}$ \\
\hline Peduncle-In (cm) & 7.7 & 6.5 & 1.9 & 0.84 & 25 & 13 & $0.26 \mathrm{~ns}$ & $0.20 \mathrm{~ns}$ \\
\hline Peduncle-out $(\mathrm{cm})$ & 7.4 & 6.6 & 1.1 & 1.4 & 15 & 21 & $-0.02 \mathrm{~ns}$ & $0.38 *$ \\
\hline Peduncle length $(\mathrm{cm})$ & 15 & 13 & 2.6 & 2.1 & 17 & 16 & $0.17 \mathrm{~ns}$ & $0.31 \mathrm{~ns}$ \\
\hline
\end{tabular}

ns, * and **:nonsignificant, significant at $5 \%$ and $1 \%$ probability level, respectively. 
Table 5. Means and deviation precentag from total mean for maize difference traits of groups in cluster analysis in heat stress condition

\begin{tabular}{|c|c|c|c|c|}
\hline \multirow[b]{2}{*}{ Traits } & Cluster 1 & Cluster 2 & Cluster 3 & \multirow{2}{*}{$\begin{array}{l}\text { Total } \\
\text { mean }\end{array}$} \\
\hline & $\begin{array}{c}1,2,3,5,7,8,9,11,12,13,14,15 \\
16,17,18,20,21,26,27,28\end{array}$ & 4,6 & $10,19,22,23,24,25$ & \\
\hline Grain yield $\left(\mathrm{Kgha}^{-1}\right)$ & $581.35,-39$ & $3032.5,+218.3$ & $1497.2,+57.2$ & 952.7 \\
\hline ASI (day) & $2.9,0$ & $2.85,-1.7$ & $2.7,-6.3$ & 2.9 \\
\hline Grain filling period (day) & $64,-1.4$ & $65.5,+0.8$ & $70.8,+9$ & 65 \\
\hline Grain filling rate $\left(\right.$ mgday $\left.^{-1}\right)$ & $4,-2.4$ & $4.7,+14.6$ & $3.9,-5.4$ & 4.1 \\
\hline Plant growth period (day) & $122.6,-1.3$ & $125.5,+1$ & $129.3,+4.1$ & 124.2 \\
\hline Grain protein percentage & $13.1,+3.2$ & $10.69,-15.8$ & $12.12,-4.6$ & 12.7 \\
\hline Grain dry matter weight (mg) & $259,-3.2$ & $305,+14$ & $283.5,+5.9$ & 267.6 \\
\hline 1000 grain weight (gr) & $310,-4.4$ & $340.5,+5$ & $366.8,+13$ & 324.4 \\
\hline Hektolitr weight $\left(\mathrm{grl}^{-1}\right)$ & $724.85,-0.76$ & $740,+1.3$ & $745.5,+2.1$ & 730.4 \\
\hline Grain moisture percentage & $15.4,+0.43$ & $14.5,-5.2$ & $15.5,+1.4$ & 15.3 \\
\hline Grain per row & $5.5,-24.9$ & $18.5,+152.7$ & $9.7,+32$ & 7.3 \\
\hline Rows per ear & $8.8,-10.1$ & $12.5,+27.7$ & $12.2,+24.3$ & 9.8 \\
\hline Grain per ear & $67.3,-25.5$ & $248,+174.6$ & $117,+29.5$ & 90.3 \\
\hline Ear diameter $(\mathrm{cm})$ & $3,-3.2$ & $3.5,+13.5$ & $3.3,+7.14$ & 3.08 \\
\hline Ear wood diameter $(\mathrm{cm})$ & $2.14,-1.3$ & $2.16,-0.69$ & $2.26,+4.2$ & 2.17 \\
\hline Grain depth $(\mathrm{cm})$ & $0.4,-11$ & $0.68,+51$ & $0.52,+14.8$ & 0.45 \\
\hline Grain width $(\mathrm{cm})$ & $0.58,-1.7$ & $0.55,-6.8$ & $0.62,+4.2$ & 0.59 \\
\hline Grain diameter $(\mathrm{cm})$ & $0.67,-2.6$ & $0.76,+10$ & $0.7,+1.9$ & 0.69 \\
\hline Grain abortion percentage & $35.6,+3$ & $27.4,-20.7$ & $28.8,-16.7$ & 34.6 \\
\hline Plant height $(\mathrm{cm})$ & $134,+2.4$ & $148.3,+13.3$ & $134.7,+2.9$ & 130.9 \\
\hline Ear height $(\mathrm{cm})$ & $56.3,+0.53$ & $66.25,+18.3$ & $58.9,+5.1$ & 56 \\
\hline Ear-up leaves & $5.8,-3.3$ & $6.2,+4.2$ & $5.8,-2.8$ & 6 \\
\hline Ear-down leaves & $6.3,-2.6$ & $6.7,+2.6$ & $6.5,0$ & 6.5 \\
\hline Total leaves & 12,0 & 12,0 & 12,0 & 12 \\
\hline Tassel length $(\mathrm{cm})$ & $36.2,0$ & $38,+5$ & $35.4,-2.2$ & 36.2 \\
\hline Tassel up $(\mathrm{cm})$ & 26,0 & $28,+7.7$ & $25.7,-1.1$ & 26 \\
\hline Branch number & $13.7,+0.92$ & $12.5,-8$ & $13.7,+0.92$ & 13.6 \\
\hline Peduncle-In $(\mathrm{cm})$ & $6.6,+1.5$ & $6.3,-3$ & $6.7,+3$ & 6.5 \\
\hline Peduncle-out $(\mathrm{cm})$ & $6.5,-1.5$ & $7.15,+8.3$ & $6.7,+1.5$ & 6.6 \\
\hline Peduncle length $(\mathrm{cm})$ & 13,0 & $14,+7.7$ & $12.8,-1.5$ & 13 \\
\hline
\end{tabular}


Table 6. Means and deviation precentages from total mean for different maize traits of groups in the cluster analysis in normal condition

\begin{tabular}{|c|c|c|c|c|}
\hline \multirow[b]{2}{*}{ Traits } & Cluster 1 & Cluster 2 & Cluster 3 & \multirow{2}{*}{$\begin{array}{l}\text { Total } \\
\text { mean }\end{array}$} \\
\hline & $\begin{array}{c}1,2,3,5,6,8,9,10,11,12,13,14 \\
16,17,19,23,24,25,26,27,28\end{array}$ & $4,20,21,22$ & $7,15,18$ & \\
\hline Grain yield $\left(\mathrm{Kgha}^{-1}\right)$ & $3160.7,+0.8$ & $4332,+38.2$ & $1362.7,-56.5$ & 3135.4 \\
\hline ASI (day) & $2.3,+3.2$ & $2.1,-4.5$ & $1.6,-27.3$ & 2.2 \\
\hline Grain filling period (day) & 71,0 & $74.8,+5.3$ & $63.7,-10.3$ & 71 \\
\hline Grain filling rate $\left(\mathrm{mgday}^{-1}\right)$ & $4.1,0$ & $4.4,+7.9$ & $4.7,+13.8$ & 4.1 \\
\hline Plant growth period (day) & 126,0 & $128,+1.6$ & $122,-2.6$ & 126 \\
\hline Grain protein percentage & $7.9,0$ & $7.8,-1.3$ & $7.9,0$ & 7.9 \\
\hline Grain dry matter weight (mg) & $287.4,-2.2$ & $326.5,+11.1$ & $295.3,+0.52$ & 293.8 \\
\hline 1000 grain weight $(\mathrm{gr})$ & $331.8,-0.66$ & $370.5,+10.9$ & $302,-9.6$ & 334 \\
\hline Hektolitr weight $\left(\mathrm{grl}^{-1}\right)$ & $708.6,+1.1$ & $672,-4.2$ & $689.7,-1.6$ & 701 \\
\hline Grain moisture percentage & $24.4,-0.16$ & $26.4,+6.9$ & $25.1,+1.6$ & 24.7 \\
\hline Grain per row & $30,+0.81$ & $29,-3$ & $29,-3$ & 29.9 \\
\hline Rows per ear & $14.2,0$ & $14.2,0$ & $14.2,0$ & 14.2 \\
\hline Grain per ear & $434.9,+0.89$ & $433.3,+0.53$ & $409.75,-4.9$ & 431 \\
\hline Ear diameter $(\mathrm{cm})$ & $4.1,0$ & $4.3,+4.4$ & $4.1,0$ & 4.1 \\
\hline Ear wood diameter $(\mathrm{cm})$ & $2.3,-3.3$ & $2.4,0$ & $2.4,0$ & 2.4 \\
\hline Grain depth $(\mathrm{cm})$ & $0.9,-1.1$ & $0.95,+4.4$ & $0.89,-1.8$ & 0.91 \\
\hline Grain width $(\mathrm{cm})$ & $0.44,0$ & $0.43,-2.3$ & $0.4,-8.3$ & 0.44 \\
\hline Grain diameter $(\mathrm{cm})$ & $0.67,-1.1$ & $0.75,+10.3$ & $0.68,0$ & 0.68 \\
\hline Grain abortion percentage & $3.3,-5.3$ & $2.9,-16.6$ & $4.7,+35.14$ & 3.5 \\
\hline Plant height $(\mathrm{cm})$ & $149.9,-0.59$ & $152.5,+1.1$ & $154,+2.1$ & 150.8 \\
\hline Ear height $(\mathrm{cm})$ & $66.9,0$ & $64.7,-3.3$ & $70,+4.5$ & 66.9 \\
\hline Ear-up leaves & $5.7,-5.3$ & $5.6,-6.25$ & $5.4,-10.6$ & 6 \\
\hline Ear-down leaves & 6,0 & 6,0 & 6,0 & 6,0 \\
\hline Total leaves & $11.8,-1.8$ & $11.5,-4.2$ & $11.5,-4.2$ & 12 \\
\hline Tassel length $(\mathrm{cm})$ & $35.4,-1.7$ & 36,0 & $39.5,+9.6$ & 36 \\
\hline Tassel up $(\mathrm{cm})$ & $25.6,-1.4$ & $26.2,+0.7$ & $29,+11.4$ & 26 \\
\hline Branch number & $12.7,-2.2$ & $13.3,+1.9$ & $11.8,-9$ & 13 \\
\hline Peduncle-In $(\mathrm{cm})$ & $7.9,+3.1$ & $7.6,-1.9$ & $6.6,-14.7$ & 7.7 \\
\hline Peduncle-out (cm) & $7.4,0$ & $7.6,+2.7$ & $7.2,-2.7$ & 7.4 \\
\hline Peduncle length $(\mathrm{cm})$ & $15.3,+2.2$ & $15.15,+1$ & $13.8,-8.2$ & 15 \\
\hline
\end{tabular}




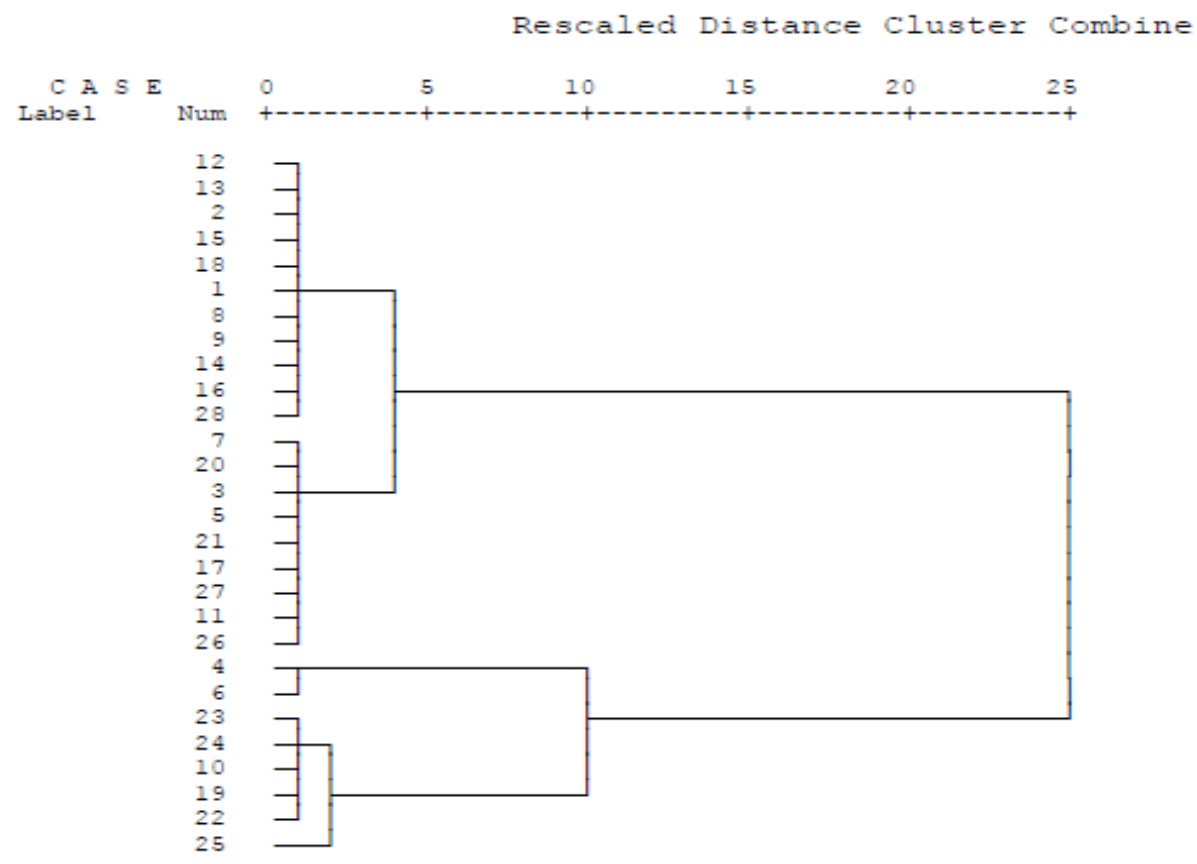

Figure 1. Cluster analysis of maize hybrids under heat stress condition
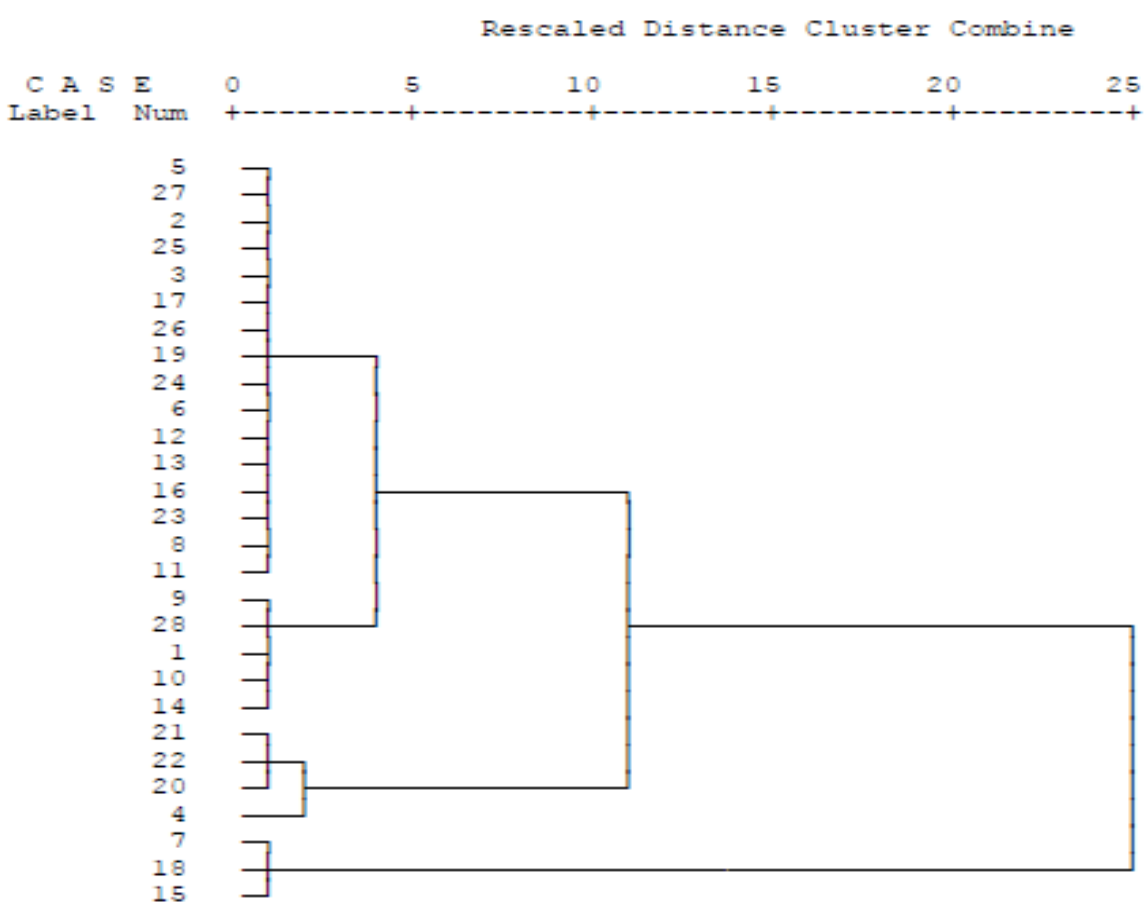

Figure 2. Cluster analysis of maize hybrids under normal condition 